\title{
Qualitative Sociology Review
}

Volume IV, Issue 1 - April 2008

DOI: https://doi.org/10.18778/1733-8077.4.1.01

\author{
Robert Prus \\ University of Waterloo, Canada
}

\begin{abstract}
On the Pragmatics and Problematics of Defining Beauty and Character: The Greek Poet Lucian (120-200) Engages Exacting Portraitures and Difficult Subjects
\end{abstract}

\begin{abstract}
Although best known as a satirist of the classical Roman era, Lucian's (c120-200CE) Essays in Portraiture and Essays in Portraiture Defended provide considerable insight into the problematics of people knowing and defining objects (along with the consequential and related matter of people sharing their definitions of reality with others).

Engaging notions of admiration, beauty, and character in these two statements, Lucian not only faces the task of establishing viable frames of reference for linguistically defining the essence of a woman deemed to be particularly beautiful and gracious but also assumes the challenge of defending one's preferred definitions of particular subject matters from others who do not share these views.

Whereas Lucian uses the works of prominent sculptors, painters, poets, and philosophers as reference points in articulating beauty and grace, this paper also acknowledges the perils of people who sincerely express their viewpoints on others even when these descriptions of others are cast in clearly positive terms.

Lucian may be a lesser-known classical Greek (Syrian) author, but he is an astute observer of human endeavor. Lucian's work on portraiture also has a striking cross-cultural and transhistorical relevance for a more enduring pragmatist emphasis on human knowing and acting. Not only is Lucian (a) explicitly attentive to the necessity of people establishing frames of reference for describing objects to others in meaningful terms, but he also overtly recognizes (b) the multiple viewpoints that people may invoke with respect to describing particular objects, (c) the resistances that people may encounter from others, and (d) the importance of speakers articulating the foundations for their claims amidst contested notions of reality.

Approached from an interactionist perspective (Mead 1934; Blumer 1969; Strauss 1993; Prus 1996, 1997, 1999), wherein attention is given to the more general matters of people acquiring perspectives, defining objects, and sustaining particular notions of reality, this paper uses Lucian's materials on portraiture as a cross-cultural and transhistorical resource both for assessing (and qualifying) existing interactionist conceptualizations of human group life and for suggesting some more particular areas of inquiry to which contemporary scholars may attend.
\end{abstract}

\section{Keywords}

Lucian; Beauty; Character; Art; Reality; Definition; Language; Resistance; Symbolic interaction 
[I]t is in virtue of qualities only that things are called similar or dissimilar; a thing is not similar to another in virtue of anything but that in virtue of which it is qualified. (Aristotle Categories 8: 11a)

Whereas notions of beauty and character, along with people's conceptions of art and poetics, are often envisioned as aesthetic and/or subjectivist, if not more extensively elusive essences, people have continued to engage these as matters of some consequence over the span of recorded history. Although those in philosophy and literature have given considerable attention to the essences and problematic features of beauty, art, and poetics, at least since Plato (c420-348BCE) and Aristotle (c348-322BCE), , social scientists have given little attention to these essences and the comparative "tastes" they seem to imply.

Still, as Dewey (1934) so aptly argues, matters of beauty, character, art, poetics, and the like merit careful, scholarly attention as realms of human knowing and enterprise. Indeed, while we may not be able to know these matters in all respects, as students of the human condition we can examine the ways in which people make sense of, as well as invoke and sustain notions of these sorts within the context of community life.

Likewise, while there is no attempt to justify or defend the things that people develop or define in more expressive or aesthetic terms, it is instructive to examine as far as we can, the ways in which people make sense of, engage, and represent, as well as more explicitly attempt to communicate to others, all manner of things.

Relatedly, rather than presume that social scientists require one theory for dealing with items that have material substance and another theory for matters deemed to be immaterial in essence, the objective in developing this statement is to contribute to a more general theory of human knowing and acting.

In what follows, I not only build on Chicago-style interactionism to arrive at a fuller understanding of the poetic venture, ii but also seek to explore, assess, and possibly extend interactionist notions pertaining to "the definition of the situation" by examining a fictionalized account of the definitional process in some detail.

Thus, in contrast to more contemporary, ethnographic depictions of people's definitions of situations (e.g., Cressey 1932; Lofland 1966; Prus and Sharper 1977; Prus and Irini 1980; Prus 1989a,b; Charmaz 1991; Karp 1996; Fine 1996, 2001), wherein the emphasis is on the analysis of actual cases, the present statement is developed around two separate but interrelated statements that were developed nearly two millennia ago by a Greek philosopher-poet.

The author, Lucian of Samosata (c120-180) would have been in no position to anticipate developments in the (contemporary) social sciences. However, Lucian was part of the broader, second (Greek) sophistic movement (c60-230CE), ${ }^{\text {iii }}$ wherein a pronounced emphasis was placed on the questioning of conventional wisdoms and practices. Consequently, whereas Lucian writes as a satirist (and poet), much of his work has a notable philosophic and (as with the two articles examined here) a sometimes more distinctively "constructionist" or "interactionist" quality. Thus, although Lucian is a lesser known Greek author writing in the Roman era, his statements on portraiture provide a remarkably insightful and valuable cross-cultural and transhistorical portrayal of the definitional process. ${ }^{\text {iv }}$ 
Lucian's work would have been even more compelling had he engaged in more extended ethnographic inquiry, but Lucian still very much speaks for "the generalized other" (Mead 1934) in developing his materials on beauty and character.

Following a brief overview of interactionist notions of beauty, character, and reality, central attention is given to Lucian's considerations of the ways in which beauty and character may be defined, communicated, contested, and defended.

\section{On Defining Beauty, Character, and Reality: An Interactionist Perspective}

Although the interactionists have given little direct attention to the matters of defining beauty or character, they have given some consideration to the somewhat related matters of (a) defining and assessing artwork (Becker 1982; Sanders 1989; Vail 1999a, b) and artistic performances (Becker 1963; Faulkner 1971; Prus and Irini 1980; Stebbins 1990; MacLeod 1993; Dietz 1994; Fine 1996; Bruder and Ucok 2000) and (b) identity work (Goffman 1959; Klapp 1964). .

As well, because they work within a broader pragmatist tradition, the interactionists (Mead 1934; Blumer 1969; Strauss 1993; Prus 1996, 1997, 1999), like Dewey (1934) would not only envision notions of beauty and character as "something in the making" but also approach these notions as aspects of the much broader matter of making sense of, or giving meanings to, the entire realm of humanly known reality.

Thus, in contrast to Plato's (Phaedo) Socrates and others who may be inclined to argue for absolute notions of beauty, truth, virtue, and the like, ${ }^{\mathrm{vi}}$ the interactionists attend to the relativist features of human notions of the world. Still, in contrast to those who may be inclined to reduce human reality to totalizing relativism or arbitrary text (discourse or speech), the interactionists attend to the matters of people doing things (activities) and engaging objects in intersubjectively meaningful, intentioned, and adjustive terms.

Similarly, while acknowledging that people may assign all manners of qualities to the objects of their awareness, the interactionists also recognize that the particular meanings that people assign to specific objects of reference have implications for the ways in which those people may think about and act toward these objects. As well, the interactionists recognize that the meanings that people attribute to objects may be subject to resistance and reconfiguration as people both engage specific objects and attend to other people with respect to those objects.

Thus, whereas people's notions of reality are problematic with respect to the meanings that people assign to particular items, people's definitions of situations also are to be viewed in process terms; as something in the making; as subject to instances of testing, resistance, negotiation and reconfiguration.

Still, something more is involved. It is essential to recognize that things have meaning to people only within the context of other things and particular objects achieve meaning only by reference to the things with which they are compared. Indeed, without contexts and comparison points, it is impossible to establish "what something is" or "is not" and, relatedly, to convey to meanings of that "something" to others. ${ }^{\text {vii }}$

In other words, it is only by invoking contexts and reference points that things become "meaningful," "objectified," and the like. Because language is built around notions of context and reference points, this fundamental aspect of "knowing" is often taken for granted. All symbols, thus, are not simply representations of things; all symbols presuppose reference points. 
Some may be inclined to dismiss people's notions of "art," "beauty," "character," and the like as things that are somewhat peripheral in the greater scheme of human affairs, but it should be appreciated that these matters need not be envisioned as trivial to the human actors defining particular situations in these terms.

From an interactionist perspective, as well, each instance in which people engage objects provides another occasion in which to develop a more viable understanding of the processes by which all manners of human reality (knowing and acting) may be achieved - as in tested, articulated, maintained, resisted, defended, compromised, and so forth. viii

\section{Encountering Lucian}

To many readers, it may seem odd that a $21^{\text {st }}$ century social scientist would reference a Greek poet from the classical Roman era in considering the ways in which people define reality. However, Lucian provides some highly instructive material on the nature of human knowing and acting. The two selections from Lucian considered here may be seen as instances of fictionalized satire. They also lack the more sustained empirical base that one associates with conventionalist or Chicagostyle ethnographic research.

Nevertheless, in developing his Essays in Portraiture Lucian provides an extended consideration of (a) the ways in which people might develop more precise accounts of things that they wish to represent for others, as well as (b) the variable receptions people's representations of things may encounter from others and (c) the ways in which they may deal with the resistances they encounter from others. The relevance of these matters to human group life may be appreciated when one realizes all of people's notions of "what is" and "what is not" not only are thoroughly rooted in the intersubjective, referential realities of the human community, but also connote a constructive process.

Lucian does not have access to some of the analytic concepts that contemporary social scientists (e.g., Mead 1934; Schutz 1962, 1964; Berger and Luckmann 1966; Blumer 1969) have developed in addressing "symbolic interaction" or accounting for "the social construction of reality." Nevertheless, Lucian generates a remarkably detailed account of the definitional process (and various contingencies within). He also provides another (cross-cultural, transhistorical) indication of the relevance of pragmatist notions of human knowing and acting across the centuries. Relatedly, rather than fault Lucian for not engaging the pragmatist venture in more distinctive interactionist or constructionist terms, contemporary scholars may derive inspiration for more focused ethnographic investigations of the definitional process by attending to Lucian's texts.

\section{Lucian - On Portraitures}

Although Lucian's Essays in Portraiture and Essays in Portraiture Defended are fictionalized accounts that are intended to be entertaining to readers, ${ }^{\text {ix }}$ these essays are less pointedly satirical than many of Lucian's other works and are especially instructive for the attention Lucian gives to the matters of people developing, articulating, conveying, assessing, resisting, and defending notions of reality. Thus, whereas the focus of attention is a young woman whom the principal speaker Lycinus and Polystratus find highly captivating, similar processes may be invoked in describing and knowing any variety of other objects. 
Lycinus: Upon my word, Polystratus, those who saw the Gorgon must have been affected by it very much as I was recently when I saw a perfectly beautiful woman: I was struck stiff with amazement and came within an ace of being turned into stone... (Lucian, Essays in Portraiture: 1)

In the dialogue that follows, two speakers Lycinus and Polystratus attempt to describe a beautiful woman. Although Lycinus knows the lady only through sight, it later becomes apparent that Polystratus also knows her through more extended association. After Lycinus attempts to describe the woman's outward appearance, Polystratus strives to depict the lady's character.

While Lycinus and Polystratus eventually decide to assemble their portrayal of Panthea into a text that all may enjoy, Lucian's Essays in Portraiture [EP] is instructive for conveying the problematics and processes by which people develop, describe, and share images of objects with others.

Since Lycinus and Polystratus are explicitly concerned about communicating their images of a particular object to others, social scientists may acknowledge the extended instances of reflectivity and role-taking (Mead, 1934) that Lucian's consideration of portraiture entails. No less, consequential, however, are the processes by which the speakers attempt to establish frames of reference for one another. Thus, readers may acknowledge the ways in which the speakers invoke the works of various sculptors, painters, poets, and philosophers in developing sharper, more comprehensive images of their focal object.

In developing this statement, I have followed the overall flow of Lucian's text so that readers might achieve a more sustained sense of the ways in which Lucian's speakers assumed their definitional tasks. Because Lucian seldom references the woman being described by name, I have maintained this (more generic) stance.

Essays in Portraiture $[E P]$ opens with Lycinus (EP: 1) telling his friend Polystratus that he has just been awestruck at the sight of a beautiful woman. Noting that Lycinus is often affected that way by boys, Polystratus is most intrigued and encourages Lycinus to describe the creature that has had such petrifying effects on him. While insisting that this woman is truly exceptional, (EP: 2), Lycinus says that she is lonian but otherwise he knows little of her background.

In the ensuing interchange, Polystratus (EP: 3 ) explicitly requests that Lycinus do his best to describe this woman's appearance in words. While noting that he will be unable to adequately portray her beauty, Lycinus proposes that he might make reference to the statues created by some famous sculptors to assist him in this task.

After asking Polystratus if he has seen certain statues of Aphrodites, Sonsandra, and Athena, Lycinus (EP: 4-5) says that by drawing on these works and selecting features from each, he may be able to arrive at an artistic composite that more aptly portrays the woman in question.

Utilizing this set of statutes as particular reference points, Lycinus subsequently details the woman's appearance including the shape of her head, hairstyle, forehead, brows, eyes, cheeks and smile.

While highly pleased with Lycinus' description to that point, Polystratus (EP: 7) informs Lycinus that he has neglected to provide any coloring to the woman he has represented. To accomplish this, Lycinus references certain painters and specific instances of their work. Selecting meticulously from these works of art, Lycinus not only portrays the woman's hair coloring, flesh tones, cheek and lip colors but also conveys the textures and coloring of her apparel. 
Then, drawing very precisely on certain descriptive expressions from the poet, Homer for further enhancement, Lycinus (EP: 8) proceeds to describe the woman's legs, eyes, arms and fingers. In addition, Lycinus (EP: 9) states, she has a heavenly gracefulness that none of the artisans could possibly duplicate.

Asked what this marvelous creature was doing at the time, Lycinus says that she was reading and conversing with her escorts. Then, continuing with his earlier task, Lycinus ( $E P: 9)$ uses the occasion to describe the lady's intriguing smile, alluring mouth, and beautiful teeth. Notably, while describing the symmetry and appearance of her teeth, Lycinus also provides contrasts with some generally less appealing teeth to indicate what her mouth did not look like.

At that point, Polystratus (EP: 10) realizes who the woman is and humorously chastises his friend for failing to recognize Panthea, the Emperor's mistress.

Continuing his commentary, Polystratus (EP: 11) acknowledges the accuracy of Lycinus' description. However, Polystratus explains, as a fellow lonian, he has had many opportunities to converse with this woman. While stating that he places much greater value on gentleness, kindness, nobility of the mind, self control, and a cultured background than physical beauty, Polystratus describes perfect beauty as existing only when these valued qualities of the mind are combined with physical beauty. He indicates, subsequently, that many women may be beautiful on a physical level but lack the sort of character he has just described.

In order that his own admiration for this woman may be more adequate, Lycinus (EP: 12) asks Polystratus to provide him with a verbal description of the woman's character. As Polystratus formulates his response, he notes that he also will need to draw on the philosophers, painters, and sculptors in developing his portraiture.

Polystratus (EP: 13-14) first discusses the woman's speech, saying that it is clear, sweet, and soft, youthful and gentle to the ear; the sort of sound that lingers delightfully in one's memory. While defining the woman's speech by providing some contrasts with what it is not, Polystratus also tries to describe the beauty of her singing voice. This seems particularly difficult and, in the end, Polystratus says that her singing voice would be of that sort one would find harmonious with the images Lycinus has provided of the woman's beautiful mouth and teeth.

Relatedly, Polystratus (EP: 15) comments on the precision of the lady's speech, her quick mind, and her ample but subtle Attic (Athenian-style) wit. He also appreciates her enthusiasm for poetry. Then, observing that his efforts so far have been somewhat inadequate, Polystratus says he will attempt to discuss her other qualities in more singular terms as opposed to following Lycinus' practice of developing composite descriptions. [It is not apparent that Polystratus can sustain this emphasis.] Lycinus says that he looks forward to Polystratus' description.

Proceeding thusly, Polystratus (EP: 16) says that culture is the most desirable of all assets, particularly acknowledging the refinements acquired through study. Finding himself at a loss to produce an established model, Polystratus states that a woman of her distinction would not only be well versed in poetics, but also would have acquired considerable depth in history and philosophy.

Polystratus (EP: 17) next focuses attention on wisdom and understanding. Citing a Socratic dialogue written by Aeschines, Polystratus likens Panthea to the woman depicted therein. Thus, she is well versed in matters of state and has a quick, penetrating mind. Referencing yet other women from the past, Polystratus describes the lady as noble, having a pleasant life-style, and able to give valuable counsel.

Somewhat relatedly, Polystratus (EP: 19) then comments on the lady's gentle, gracious disposition. Here, Polystratus compares her to some earlier women considered well known for these qualities. 
In a similar fashion, Polystratus (EP: 20) also attests to Panthea's modesty and her love for the Emperor. Continuing, Polystratus (EP: 21) stresses that despite her elevated status, she has maintained her graciousness. Not only has she avoided all aspects of vulgarity but she also treats all visitors as equals. Likewise, Polystratus observes, by exercising such moderation and modesty, the lady avoids the envy that is associated with the low-minded, pretentious, or arrogant styles frequently associated with others who enjoy good fortune. Instead, her mannerisms are so gracious that all of her acquaintances only pray for her continued good blessings.

As Polystratus concludes his portraiture of her character, Lycinus (EP: 22) applauds Polystratus' description, adding that it is most fitting that someone as good and gentle as the Emperor would find a woman so exceptional to love and love him. Indeed, Lycinus concludes, there is no mortal woman that can compare with her.

Recognizing that he and Lycinus are of one mind on this matter, Polystratus $(E P: 23)$ proposes that they put their portraitures together into a book; a statement to be appreciated by all of mankind on an enduring basis. Polystratus also contends that a text of this sort would provide a more pleasing representation for the lady than anything that artists might create in statues, paintings, and the like. In addition to its authenticity, their statement would reveal both her physical beauty and the graciousness of her character.

\section{Essays in Portraiture Defended (EPD) $)^{\mathrm{xi}}$}

Polystratus: ... see how you can refurbish the book... To be sure, when I heard it first I did not see a single fault in what you had written, but now that she has pointed them out, I myself begin to think as she does about it. (Lucian, Essays in Portraiture Defended: 12)

In opening this dialogue, Polystratus (EPD: 1-6) indicates that Panthea has read the composite portraiture that Lycinus and Polystratus have developed for her. Polystratus now delivers her response to Lycinus. [Readers may note that although the essay submitted to Panthea was developed by both authors and Polystratus acknowledges joint authorship at times, Lucian's text reads as if Lycinus is the only author at other points in the dialogue.]

While acknowledging the authors' very kind gesture in developing their statement as well as the high esteem in which they apparently hold her, the lady indicates that she cannot condone flattery. She further states that whatever exceeds the boundaries of authenticity constitutes flattery. She notes that many people like to be flattered and she provides some instances of women who have been receptive to such portrayals. She, however, wishes to have none of that.

Polystratus (EPD: 7) says that the lady commended the portraiture in many respects. Nevertheless, she considered it highly inappropriate to be compared to the great ladies of the past and especially objected to comparisons that the authors had drawn between goddesses such as Hera and Aphrodite and herself. Polystratus adds that the lady views herself as superstitious and is fearful in all matters involving the gods.

Further relaying her concerns, Polystratus (EPD: 8-11) says that Lycinus must rewrite all references of these sorts. While acknowledging the authors' talent, the lady considers it sinful to allow herself to be likened unto the gods and simply cannot accept such references.

Then, speaking more directly on his own behalf, Polystratus (EPD: 12) reaffirms the validity of the lady's viewpoint. Polystratus says that he had earlier viewed 
Lycinus' statements as flawless, but now shares her assessments. Indeed, it is highly disrespectful to the gods to liken any human unto them. Continuing, Polystratus suggests that Lycinus might refer to mortal women in order to provide more acceptable comparisons. Then, noting that Lycinus seldom has been generous in his assessments of others, Polystratus encourages Lycinus to be more restrained in his compliments in this case. As well, Polystratus says, even the great sculptor Phidias [also Pheidias] extensively reworked a statue of Zeus after encountering critical commentaries when it had been publicly displayed. Polystratus encourages Lycinus to acknowledge the advantage of multiple viewpoints over the one.

Responding to the lady's message and Polystratus' commentary, Lycinus (EPD: 15) says that Polystratus not only has delivered a lengthy message, but also has condemned the book without providing an adequate opportunity for Lycinus to defend himself. Attending to his friend's viewpoint, Polystratus says that he is not only ready to listen to any defense Lycinus might offer but would prefer to align himself with Lycinus as a co-defendant.

Noting that he will not be able to address this lady directly, but will have to rely on Polystratus as a messenger, Lycinus (EPD: 16) says he will try to be succinct. Lycinus observes that he is quite apprehensive about the whole matter, but can see no way out. After reminding Lycinus of the lady's exceedingly gracious and congenial manner, Polystratus encourages Lycinus to venture forth. [In what follows, Lycinus develops a series of defenses for his definitions of Panthea. Each of these will be identified in turn.]

Lycinus (EPD: 17) begins by acknowledging the lady's concern about the gods. However, Lycinus does not defend what he said. Instead, Lycinus contends that the lady's response, which displays her great reverence for the gods, indicates that he has said less than he should have. If he were to correct the portraiture, to make it more accurate, Lycinus would have to comment on her exceedingly noble character as evidenced by her humility, respect, and devotion to the gods.

Second, while noting that he praised her character, Lycinus (EPD: 17) says that the lady has confirmed the validity of his claims about her humility by the particular things she censored in his text. Lycinus emphasizes that it is those who are least willing to be praised that most merit praise. Lycinus (EPD: 18) also notes that while poets and painters often know no boundaries in their enthusiasm for expressing and exciting admiration for their subjects, he will take no refuge in this latter viewpoint.

Still, Lycinus (EPD: 19) states, it is important to recognize the limitations with which authors work. Although it is necessary to develop comparisons and to use similes (or metaphors), it is essential that the comparisons are viable. When something is seen as exemplarily, Lycinus states, it is not enough to compare it with things that are generally equivalent or with things of notably lesser quality. Instead, one needs to compare exceptional objects with more worthy comparison points. Otherwise, Lycinus contends, the praise or admiration that one has for a particular object will appear mundane and pointless.

Lycinus (EPD: 20-22) next turns to the matter of flattery. While openly commending the lady's distaste for flattery, Lycinus stresses the difference between genuine admiration and the exaggeration of flatterers. ${ }^{\text {xii }}$ Noting that flatterers have little regard for the truth, but instead readily misrepresent all manners of things for personal gain, Lycinus says that admirers sincerely focus attention on the particular matters that they value. Relatedly, he states, it is inappropriate to distrust all who praise one in certain respects. Instead, it is important to distinguish and assess each speaker accordingly. Lycinus then proposes that the lady examine the claims he has 
made about her beauty and see if there is not substantial evidence for the likenesses he has identified.

Then, returning to the lady's objection to being compared to the goddesses, Lycinus (EPD: 23) notes that he did not actually compare her with the goddesses themselves but instead has likened her to the masterpieces of distinguished craftsmen. Arguing that it is not impious to compare humans with things generated by human artists, Lycinus also draws attention to the inabilities of humans, even with their very best efforts, to adequately represent the gods.

Developing yet another line of defense, Lycinus (EPD: 24-26) continues. He says that even if he had compared the lady directly to the goddesses referenced in his text, he would not have been the first to make comparisons of these sorts. Indeed, the poets, of whom Homer is most notable, have long done so. Lycinus then asks if Homer or his work is to be rejected on this basis.

Further, Lycinus (EPD: 27) adds, on another level, it is of comparatively little relevance if people are likened unto gods. Thus, Lycinus observes that many Greeks are named after particular gods and acknowledges that the Egyptians pursue this practice even more extensively than the Greeks.

Then, addressing Panthea's fears in more direct terms, Lycinus (EPD: 28) says that the lady has no reason to be apprehensive about the praise that has been directed toward her. Assuring her that she is not accountable for the deeds of others, Lycinus says that it is he, as the author, whom the gods would punish. Still, Lycinus emphasizes, Homer and the other poets would precede Lycinus in these matters, as presumably also would those philosophers who claim that people have been created in God's image.

The dialogue (EPD: 29) ends with Polystratus planning to deliver Lycinus' message promptly to the lady. Lycinus expects that his defense will encounter a favorable reception.

\section{In Perspective}

Although Essays in Portraiture and Essays in Portraiture Defended are fictionalized accounts set in another place and time, Lucian's considerations of the ways that people develop, share, resist, and reaffirm definitions of objects has a pronounced relevance to contemporary social scientists' interest in human knowing and acting.

Not only does Lucian provide us with material that has a valuable transcultural and transhistorical nature, but Lucian's attention to multiple viewpoints, comparison points, and linguistically-enabled intersubjectivity has an enduring relevance as also does his consideration of contested and defended viewpoints.

Expressed in other terms, Lucian's texts represent instructive depictions of people's definitions of reality, the problematics of effective communication (limitations of language, locating common reference points, achieving precision and adequacy in developing descriptions, and the use of composites, analogies and metaphors), and aspects of influence work (promoting definitions, encountering resistance, and defending positions).

That Lucian's texts revolve around beauty and character, focus on a particular young woman, or have an intendedly entertaining quality, should not detract present day scholars from the more fundamental, generic, or enduring quest on the part of humans to know (as in identifying, comparing, describing, sharing, testing, assessing, contesting, readjusting, and defending) all objects of their awareness. 
Relatedly, rather than envisioning Lucian's texts as antiquated, frozen in time, or poetically idiographic, we can situate Lucian's texts within the larger set of resources that address people's "definitions of the situation (or reality)." Building on the insights that Lucian provides, we might give more attention to the ways that people sharpen and retain their own images of things and how they share these notions with others in linguistic (and other) representations.

Thus, for instance, more focused consideration could be given to the reference points that people invoke in locating, describing, and giving meanings to things, the ways in which people invoke, reject, and resist comparisons (similarities and differences) in defining and conveying images of specific things, and people's use of analogies and (the typically more expressive) metaphors to draw attention to particular features of objects.

Of relevance as well, are people's abilities to resist, contest, and revise definitions that they deem inappropriate as well as people's tendencies to reaffirm those definitions that they consider more viable. While these notions have been particularly prominent in "labeling theory" and interactionist notions of deviance (see Lemert 1951, 1967; Garfinkel 1956; Becker 1963; Goffman 1959, 1963; xiii Prus and Gills 2003), it also might be observed that related matters of contested identities have been discussed at length by various Greek and Latin scholars (especially Aristotle, Cicero, Quintilian) in their analysis of rhetoric (Prus in progress). . $^{\mathrm{iv}}$

As well, rather than dismiss art and people's aesthetic judgments as beyond the realms of knowledge and study (as suggested in notions of unrestrained spontaneity or unbridled emotional expressivity), Lucian engages matters of beauty and character as intersubjectively achieved essences. Thus, although there is no indication the Lucian is familiar with either Aristotle's Poetics or Horace's On the Art of Poetry, Lucian engages artistic definitions of the situation in ways that lend themselves to detailed investigations and scholarly analyses (also see Dewey 1934; Becker 1982). ${ }^{\mathrm{xv}}$

In concluding this paper, one more caveat may be in order. This revolves around the distinction between social scientists benefiting from poetical endeavor as a scholarly resource versus social scientists becoming caught up in poetic intrigues and ventures as modes of scholarship, expression, entertainment, and morality.

As social scientists, we can be extremely grateful to Lucian and the other authors of the classical Greek and Latin eras for the incredible literary legacy they have bequeathed us. These materials have been foundational in forming and enabling our own intellectual developments across wide ranges of scholarly endeavor as well as constituting historical documents for comprehending particular eras of Western civilization.

Clearly, not all of the materials from the classical Greek and Latin eras are of equal value for the study of human lived experience. Indeed, only a small portion of the poetical or fictionalized literature contains material that addresses the human condition in more sustained, detailed, and explicit manners. ${ }^{\text {xvi }}$ However, as suggested in this paper, these latter materials represent resources that social scientists may use in assessing and refining concepts of more generic (transsituational and transhistorical) sorts as well as sources of intellectual stimulation for subsequent research.

Still, it should be emphasized that the value of these materials to those in the social sciences does not derive from their intendedly playful or entertaining qualities or the artistic manners in which these materials have been developed. 
Instead, given their interests in the study of human group life, the "beauty" and "character" of these works for social scientists comes from the more sustained attention that these particular authors have given to the study of knowing and acting.

We can appreciate the substantive portrayals of human group life as well as certain conceptual (philosophic) insights that Lucian and some other Greek and Latin poets introduce in their texts. Likewise, it should be acknowledged that we have no historical substitutes for most of the works that these authors have produced.

However, because of the mixed and virtually unlimited licenses that poets may assume with respect to their subject matters, experiences, sources, analysis, moralities, representations, and emotional expressions, it is much more difficult to assess the substantive value of materials that are framed in poetic terms.

Accordingly, contemporary social scientists would be ill-advised to imitate the poetic qualities of these endeavors in pursuing their research, analysis, and eventual representation of the human condition in their texts. Quite directly, while poetical works can be informative and suggestive in various ways, their fictionalized emphases are not to be envisioned as viable substitutes for more sustained ethnographic research. .vii $^{\text {vi }}$

As social scientists, we may scrutinize (and value) poetic (fictionalized) endeavors for any insights they may offer about the human condition as well as for suggestions for more focused realms of inquiry. However, we also need to be attentive to the many questionable elements of these materials and engage the poetics literature with considerable skepticism.

In particular, it is important that social scientists be extremely cautious about invoking, using, or referencing emotionally evocative features of fictionalized (as in fantasized, dramatized, particularized, moralized, idealized, and linguistically amplified) materials in depicting aspects of human group life that they themselves have not investigated in highly sustained detail. xviii

Indeed, only by (a) attending more directly and conscientiously to one's assumptions about human knowing and acting and (b) approaching all texts in more discerning and precise conceptual and comparative terms, may we (c) benefit from the materials that those poets of the past (and present) who deal with human knowing and acting in more detailed and sustained terms and (d) develop projects and analyses that have greater clarity, depth, rigor, authenticity, and enduring relevance for the study of human group life.

\section{Endnotes}

i See Plato's Republic, Laws, Ion, and Symposium as well as Aristotle's Poetics.

ii Following Aristotle (Poetics) more generally, the term poetics is used to refer to deliberatively fictionalized linguistic materials intended to have an entertaining quality (regardless of whether these are developed in rhyme or prose, presented on their own or in conjunction with enactments, props, music and the like).As Aristotle also observes: unlike historians and others who more faithfully claim to represent particular instances of things, poets are not restricted to highly specific cases in developing their representations of things. Thus, although they need not be concerned with such matters, poets have the opportunity to develop concepts, insights, and other depictions that have more (philosophic) universalistic or generic analytic qualities than do people developing materials as historians or others intent on portraying particular 
cases. Further, readers may appreciate that even when certain aspects of poets' texts are notably fictionalized, poets may still maintain considerable authenticity in representing other aspects of the phenomenon under consideration.

iii Others who may be included within the second sophist movement include Dio Chrysostom (c40-120CE), Plutarch (c46-125CE), and Sextus Empiricus (c200CE)

iv Contemporary scholars who lack direct familiarity with the texts written in the classical Greek and Latin eras are apt to be struck by the overall quality (conceptual fullness, depth, detail, clarity, and comprehensiveness) of these materials.

Identity work, as in notions of self and others and deviance and respectability, represents a central analytic theme or generic social process in the interactionist literature. For overviews of the conceptual and ethnographic materials developed by those in the interactionist tradition, see Prus (1996, 1997, 1999) and Prus and Grills (2003).

vi Although Plato engages notions of absolute reference points and ideal forms in other of his dialogues, Plato does not sustain this viewpoint in his considerations of city states (e.g., Republic, Laws) or in his dialectic analysis of human knowing (e.g., Phaedrus, Philebus). Thus, while Plato (a) argues for a divinely-enabled pure realm of knowledge when adopting theological stances, Plato also asks (b) whether anything can be humanly known and, at other times still, (c) focuses on the pragmatist (knowing and enacted) features of human community life.

vii The pragmatist insight, that nothing has meaning unto itself, is not unique to the interactionist or American pragmatists, but is discussed in rather explicit terms by Aristotle (c384-322BCE) in Categories. For a fuller consideration of the Greek roots of contemporary pragmatist scholarship, see Prus (in press).

viii Although people may define "art" and "beauty" in many different ways, notions of beauty seem central to people's attentiveness to art (material as well as poetic) -- both as producers or makers of art and as consumers (observers, assessors, critics). Thus, whereas people may have very different, often highly contradictory notions of beauty, beauty is apt to be defined by people's definitions of what is good, desirable, intriguing, or pleasurable. Thus, what qualifies as "art" (versus banality, incongruity, incompetence, waste, ugliness, offensiveness) is contingent on people's senses of beauty in productive as well as consumptive modes of engaging particular subject matters more generally and the actual instances in which people attend to things. Relatedly, as Dewey (1934) emphasizes, the roles of the producer and the consumer are not as separate as they often are assumed. Thus, artists routinely also take on the role (i.e., assume the viewpoint) of consumers or audiences as artists develop (envision, engage, assess, and re-engage) particular instances of [artwork] and consumers also assume the role of artists whenever consumers attend to instances of [artwork] as something that would be envisioned and produced by minded, purposive agents. Likewise, it also should be noted that both producers and consumers of particular objects may retain as well as reformulate their images and assessments of these items overtime. Thus, the same people may reaffirm earlier standpoints and interpretations as well as adopt very different 
notions of beauty and art as they engage and re-engage particular human productions. Notably, too, while consumers or audiences may be (a) seen as fickle, (b) presumed to operate with limited perspectives when defining beauty and art; and (c) accused of lacking the specific viewpoints or sensitivities that producers may have in generating the items under consideration, it also may be appreciated that artists (as producers) may be among their own most severe critics. Hence, producers not infrequently refer to objects (that they, themselves, formerly had envisioned as art or art in the making) as junk, trash, and the like, and may be adamant about destroying their own productions because they no longer represent instances of "art" from one or other perspectives that the producers have brought to bear on these instances. Whereas Dewey (1934) addresses both material (plastic) and poetic (linguistic) art, readers also may like to examine Rosenblatt's (1978) The Reader, The Text, and The Poem. Attending to reading as activity, Rosenblatt's statement builds centrally on Dewey's pragmatist analyses.

ix Because Lucian provides no explanation of the source of his portraitures, it is inappropriate to claim ethnographic integrity for these essays. Still, this does not preclude elements of authenticity in his essays, nor does this destroy the value of the more prototypic processes that Lucian addresses therein. Relatedly, although Lucian gives the woman in question a specific identity and speaks of her in the most laudatory of terms, he seldom uses her name in developing either essay on portraiture. Those who know Lucian's other texts (e.g., On Sacrifices, On Funerals, Zeus Rants, Zeus Catechized, Philosophies for Sale, The Double Indictment, Slander) may appreciate the notable relativist, multiplistic, and generic emphases that Lucian introduces into his work more generally. For an interactionist / constructionist consideration of some of Lucian's work on religion, see Prus (2003).

X I am indebted to A.M. Harmon's (1925) translation of Essays in Portraiture in Lucian (Vol. IV: 255-295). The numeral references to this statement $(E P)$ are to the standardized notations accompanying the Greek text in the (Greek-English) Loeb edition. Although Harmon (Lucian IV: 255) uses the term portraiture to refer to the verbal descriptions that Lucian's speakers develop to represent the object under consideration, Harmon also indicates that there is no direct translation for the Greek term eikon. Since eikon refers to any portrayal or likeness, the representations implied within this term more generally would also encompass people's sketches, paintings, and sculptures.

xi I am indebted to A.M. Harmon's (1925) translation of Essays in Portraiture Defended in Lucian (Vol. IV: 297-335). The numeral references to this statement $(E P D)$ are to the standardized notations accompanying the Greek text in the (Greek-English) Loeb edition.

xii It is not apparent that Lucian has read Plutarch's (c46-125) "How to Tell a Flatterer from a Friend" (Plutarch's Moralia, Vol. I), but it seems more likely that Lucian would have had access to Plutarch's (Greek) texts than those of Latin authors such as Cicero and Ovid who have written on somewhat related topics.

xiii Because both authors so extensively focus on image work, Lucian statements on portraiture can be likened to Erving Goffman's (1959) The Presentation Self in Everyday Life and (1963) Stigma in a number of respects. Nevertheless, whereas Goffman concentrates on the ways in which (a) people manage the impressions that they give off to others and (b) those attending to these matters 
make inferences about these targets (based on these impressions and other information that the audiences may possess with respect to those targets), Lucian more directly addresses (c) the ways that people articulate and share images of specific targets with others, particularly in instances in which they endeavor to be precise and comprehensive in their depictions of those people.

xiv Whereas Lucian displays a noteworthy fluency with rhetoric in many of his texts (including the present material on portraitures), Lucian also engages rhetoricians somewhat more directly in satirical analysis (see Lucian's The Double Indictment).

$\mathrm{XV}$ Lest Lucian's analysis of the definitional process be seen as confined to notions of beauty, it might be noted that Lucian develops somewhat parallel constructionist considerations of human knowing and acting with respect to people's representation of divinity and their participation in religious life-worlds (Prus 2003). Also as noted in Lucian's Philosophies for Sale, The Dead Come to Life, and Hermotimus, Lucian is no less attentive to the problematics of defining the essence of philosophy (as in delineating, contrasting, and questioning the subject matters, practices, and roles of those who profess to be practitioners of philosophy).

xvi Although only some of their poetic materials have a more distinctive analytic (versus expressive, fantastic, moralist, religious, idealist, or entertainment) emphasis, readers also may include Ovid (43BCE-18CE), Dio Chrysostom (40$120 \mathrm{CE}$ ), and Plutarch (46-125CE) among the classical philosopher poets or poetic philosophers. Ironically, while Plato (420-348BCE; Republic, Laws) generally is severely critical of poetic representations, Plato may be seen as the most poetic of the philosophers. Further, whereas the preserved texts of Aristotle are among the most scholarly instances of prose ever generated, Aristotle's Poetics is the single most astute and conceptually enabling analysis of poetics on record.

xvii If I seem to be laboring over this point, it is only because a number of people who profess to engage the study of the human condition as "social scientists" appear to have lost perspective on the distinctions between poetic endeavor and the methodological detachment and conceptual precision required of those embarking on a more responsible social science. Also see Schwalbe (1995).

xviii Since they have access to theory, methods, and a body of research materials that deal with human knowing and acting in highly situated terms, contemporary social scientists appear able to make more much viable contributions to the study of human knowing and acting by pursuing more conventional ethnographic research than by embarking on their own poetical ventures.

\section{Acknowledgements}

I would like to thank Matthew Burk, Lorraine Prus and Beert Verstraete for their helpful comments on earlier drafts of this paper. 


\section{References}

Aristotle [1984] The Complete Works of Aristotle. Edited by Jonathan Barnes. Princeton, NJ: Princeton University Press

-----. [1915/1946] The Works of Aristotle. Edited by W. D. Ross. 11 volumes. London: Oxford University Press

Becker, Howard S. (1982) Art Worlds. Berkeley, CA: University of California Press.

-----. (1963) Outsiders: Studies in the Sociology of Deviance. New York: Free Press

Berger, Peter and Thomas Luckmann (1966) The Social Construction of Reality. New York: Doubleday-Anchor.

Blumer, Herbert (1971) "Social Problems as a Collective Behavior." Social Problems $1: 298-306$

-----. (1969) Symbolic Interaction. Englewood Cliffs, N.J.: Prentice-Hall.

Bruder, Kurt A. and Ozum Ucok (2000) "Interpretive Art Interpretation: How Viewers Make Sense of Paintings in Conversation." Symbolic Interaction 23:337-358.

Charmaz, Kathy (1991) Good Days Bad Days: The Self in Chronic Illness and Time. New Brunswick, NJ: Rutgers University Press.

Cicero [1962] Orator. Translated by H. M. Hubbell. Cambridge, MA: Harvard University Press

-----. [1962a] Brutus. Translated by G. L. Hendrickson. Cambridge, MA: Harvard University Press

-----. [1949] De Inventione. Translated by H. M. Hubbell. Cambridge, MA: Harvard University Press

-----. [1942] De Oratore. Two Volumes. Translated by E. W. Sutton and H. Rackham. Cambridge, MA: Harvard University Press

Cressey, Paul (1932) The Taxi-Dance Hall. University of Chicago Press.

Dewey, John (1934) Art as Experience. New York: Perigee (Penguin).

Dietz, Mary Lorenz (1994) "On Your Toes: Dancing Your Way into the Ballet World." Pp. 66-84 in Doing Everyday Life: Ethnography as Human Lived Experience, edited by Mary Lorenz Dietz, Robert Prus and William Shaffir. Toronto, ON: Copp Clark Longman.

Dio Chrysostom [1913/1932] Dio Chrysostom. MA: Harvard University Press

Faulkner, Robert R. (1971) Hollywood Studio Musicians: Their Work and Careers in the Recording Industry. Chicago: Aldine-Atheron.

Fine, Gary Alan (2001) Gifted Tongues: High School Debate and Adolescent Culture. Princeton, NJ: Princeton University Press.

(1996) Kitchens: The Culture of Restaurant Work. Berkeley, CA: University of California Press.

Garfinkel, Harold (1956) "Conditions of Successful Degradation Ceremonies." American Journal of Sociology 61: 420-424. 
Goffman, Erving (1963) Stigma: Notes on the Management of Spoiled Identity. Englewood Cliffs, N.J.: Prentice-Hall.

-----. (1959) Presentation of Self in Everyday Life. New York: Anchor.

Homer [1991] The Odyssey. Translated by E. V. Rieu. New York: Penguin

-----. [1990] The lliad. Translated by Robert Eagles, with an Introduction by Bernard Knox. New York: Penguin

Karp, David A. (1996) Speaking of Sadness: Depression, Disconnection and the Meanings of Illness. New York: Oxford University Press.

Lemert, Edwin (1967) Human Deviance, Social Problems and Social Control. Englewood Cliffs, N.J.: Prentice-Hall

----. (1951) Social Pathology. New York: McGraw-Hill.

Lofland, John (1966) The Doomsday Cult: A Study in Conversion, Proselytization and Maintenance of Faith. New York: Irvington Publishers (1977).

Lucian [1913/1967] Lucian. Eight volumes. Cambridge, MA: Harvard University Press.

MacLeod, Bruce A. (1993) Club Date Musicians: Playing the New York Party Circuit. Urbana, IL: University of Illinois Press.

Mead, George H. (1934) Mind, Self and Society. Chicago: University of Chicago Press.

Ovid [NO DATE] The Loves, The Art of Beauty, The Remedies for Love, and The Art of Love. Translated By Rolfe Humphries. Bloomington, IN: Indiana University Press.

Plato [1997] Plato: The Collected Works. Edited by John M. Cooper. Indianapolis: Hackett

-----. [1961] The Collected Dialogues of Plato. Edited by Edith Hamilton and Huntington Cairns. Princeton, NJ: Princeton University Press.

-----. [1937]The Dialogues of Plato. Edited by Benjamin Jowett. New York: Random House1937.

Plutarch [1927/1936] Plutarch's Moralia. Sixteen volumes. Translated by multiple authors. Cambridge, MA: Harvard University Press

-----. [1914/1926] Plutarch's Lives. Eleven volumes. Translated by multiple authors. Cambridge, MA: Harvard University Press

Prus, Robert (2003) "Objectifying Religious Beliefs, Practices, and Representations: Dio Chrysostom (40-120), Lucian (120-180), and the Constructionist Motif." Paper presented at the Association for the Sociological Study of Religion meetings in Atlanta, GA, August 15-17.

-----. (1999) Beyond the Power Mystique: Power as Intersubjective Accomplishment. Albany, NY: State University of New York Press.

. (1997) Subcultural Mosaics and Intersubjective Realities: An Ethnographic Research Agenda for Pragmatizing the Social Sciences. Albany, NY: State University of New York Press.

(1996) Symbolic Interaction and Ethnographic Research: Intersubjectivity and the Study of Human Lived Experience. Albany, NY: State University of New York Press. 
-----. (1989a) Making Sales: Influence as Interpersonal Accomplishment. Newbury Park, CA: Sage.

-----. (1989b) Pursuing Customers: An Ethnography of Marketing Activities. Newbury Park, CA: Sage.

-----. (in press) "Ancient Precursors to Symbolic Interaction: Pragmatist Dimensions of Early Greek Scholarship." in Handbook of Symbolic Interactionism, edited by Larry Reynolds and Nancy Herman. Walnut Creek, CA: Altamira.

-----. (in progress) Classical Rhetoric, Contested Realities, and the Human Sciences: Pragmatist Motifs in Greek, Latin, and Contemporary Considerations of Influence Work (ms. in preparation)

Prus, Robert and Scott Grills (2003) The Deviant Mystique: Involvements, Realities, and Regulation. Westport, CN: Praeger.

Prus, Robert and Styllianoss Irini (1980) Hookers, Rounders, and Desk Clerks: The Social Organization of the Hotel Community. Salem, WI: Sheffield

Prus, Robert and C.R.D. Sharper (1991) Road Hustler: Grifters, Magic, and the Thief Subculture. New York: Kaufman and Greenberg.

(1977) Road Hustler: The Career Contingencies of Professional Card and Dice Hustlers. Lexington, MA: Lexington Books.

Quintilian [NO DATE] The Institutio Oratoria of Quintilian (Four Volumes). Translated by H. E. Butler. Cambridge, MA: Harvard University Press.

Rosenblatt, Louise (1994) The Reader, The Text, and The Poem: The Transactional Theory of the Literary Work. Carbondale, IL: Southern Illinois University Press.

Sanders, Clinton (1989) Customizing the Body: The Art and Culture of Tattooing. Philadelphia: Temple University Press.

Schutz, Alfred (1962) Collected Papers II: Studies in Social Theory. The Hague: Martinus Nijhoff.

-----. (1964) Collected Papers I: The Problem of Social Reality. Hague: Martinus Nijhoff.

Schwalbe, Michael (1995) "The Responsibilities of Sociological Poets." Qualitative Sociology 18: 393-413.

Sextus Empiricus [1933] Outlines of Pyrrhonism. Four volumes. Translated by R. G. Bury. Cambridge, MA: Harvard University Press

Stebbins, Robert (1990) The Laugh Makers: Stand-up Comedy as Art, Business, and Life-Style. Kingston, Ontario: McGill-Queen's University Press.

Strauss, Anselm (1993) Continual Permutations of Action. Hawthorne, NY: Aldine de Gruyter.

Vail, D. Angus (1999a) "The Outside of a Thigh is Half a Back: Negotiating the Canvas among Fine Art Tattoo Collectors." The Journal of Arts Management, Law, and Society 28:261-276.

-----. (1999b) “Tattoos are Like Potato Chips ... You Can't Have Just One: The Process of Becoming and Being a Collector." Deviant Behavior 20:253-273. 


\section{Citation}

Prus, Robert (2008) "On the Pragmatics and Problematics of Defining Beauty and Character: The Greek Poet Lucian (120-200) Engages Exacting Portraitures and Difficult Subjects." Qualitative Sociology Review, Vol. IV Issue 1. Retrieved Month, Year (http://www.qualitativesociologyreview.org/ENG/archive_eng.php) 